\title{
PEMBENTUKAN PERATURAN DAERAH TENTANG RENCANA TATA RUANG WILAYAH (RTRW) PROVINSI RIAU: DINAMIKA DAN PERMASALAHANNYA
}

\author{
Suparto \\ Fakultas Hukum Universitas Islam Riau \\ Jl. Kaharuddin Nasution 113, Air Dingin, Pekanbaru, Riau 28284 \\ suparto@law.uir.ac.id SUPARTO
}

\begin{abstract}
Regional Regulation (Perda) is a regulation made by the Regional Head together with the DPRD that fulfills the elements of welfare and usefulness of a region. One of the Regional Regulations that has a strategic function is the Regional Regulation on Regional Spatial Planning (RTRW) because that is where land allocation is in accordance with the functions of the area regulated. However, the drafting of the RTRW Regional Regulation is not easy to differ from other local regulations because many interests must be considered and accommodated in its compilation including the drafting of the Riau Province RTRW Perda. After going through a very long process, the establishment of regional regulations was finally determined by The Governor of Riau, namely Regional Regulation Number 10 Year 2018 concerning the Riau Province Regional Spatial Plan with the following details: (1). Cultivation Area $=8,067,344 \mathrm{ha}$. (2). Protected area covering an area of 945,532 ha, with a total area of 9,012,886 ha. Although the Regional Regulation concerning the Riau Province RTRW has been established, there are still problems that must be resolved, namely concerning the emptying of areas that have become oil palm plantations in forest areas. This is not an easy job because it has to cut down oil palm trees with an area of hundreds of thousands of hectares. Based on Law Number 12 Year 2011 there is no difference between the Provincial RTRW Perda and other Perda or having the same position both in terms of position and formation procedures. Whereas in the process of establishing a Provincial Regional Spatial Planning Regulation involving many agencies and ministries, among others, the Ministry of Home Affairs, the Ministry of Environment and Forestry, the Ministry of National Development Planning/BAPPENAS, the Ministry of Agriculture and Spatial Planning and the Geospatial Information Agency.
\end{abstract}

Keywords: Formation, Regional Regulation, Spatial Planning

\begin{abstract}
Abstrak
Peraturan daerah (Perda) merupakan peraturan yang dibuat oleh Kepala Daerah bersama DPRD yang memenuhi unsur-unsur kesejahteraan dan kedayagunaan suatu daerah. Salah satu Perda yang mempunyai fungsi strategis adalah Perda tentang Rencana Tata Ruang Wilayah (RTRW) karena di situlah peruntukan lahan sesuai dengan fungsi kawasannya diatur. Akan tetapi penyusunan Perda RTRW ini tidaklah mudah berbeda dengan Perda-perda yang lain karena banyak kepentingan yang harus dipertimbangkan dan diakomodir dalam penyusunannya termasuk dalam penyusunan Perda RTRW Provinsi Riau.Setelah melalui proses yang sangat panjang, pembentukan peraturan daerah (Perda) tersebut akhirnya ditetapkan oleh Gubernur Riau yaitu Perda No.10 Tahun 2018 Tentang Rencana Tata Ruang Daerah Provinsi Riau dengan perincian sebagai berikut : (1). Kawasan Budidaya seluas $=8.067 .344$ ha. (2). Kawasan Lindung seluas $=$ 945.532 ha, dengan total luas keseluruhan sebesar 9.012 .876 ha. Walaupun Perda tentang RTRW Provinsi Riau telah ditetapkan tetapi masih ada permasalahan yang harus diselesaikan yaitu menyangkut pengosongan areal yang telah menjadi perkebunan kelapa sawit di kawasan hutan. Hal ini bukanlah pekerjaan mudah karena harus menebang pohon sawit dengan luasan ratusan ribu hektar.Berdasarkan Undang-Undang Nomor 12 Tahun 2011 tidak ada perbedaan antara Perda RTRW Provinsi dengan Perda-Perda yang lain, baik dalam hal kedudukan maupun tatacara pembentukannya. Padahal dalam prakteknya, proses pembentukan Perda Tata Ruang Wilayah Provinsi melibatkan banyak instansi dan kementerian antara lain, Kementerian Dalam Negeri, Kementerian Lingkungan Hidup dan Kehutanan, Kementerian Perencanaan Pembangunan Nasional/BAPPENAS, Kementerian Agraria dan Tata Ruang dan Badan Informasi Geospasial.
\end{abstract}

Kata Kunci : Pembentukan, Perda, Tata Ruang 


\section{Pendahuluan}

Peraturan Daerah (Perda) merupakan peraturan yang dibuat oleh pemerintah daerah bersama DPRD yang memenuhi unsur-unsur kesejahteraan dan kedayagunaan suatu daerah. Adanya Perda karena negara Indonesia adalah negara yang berdasarkan Otonomi Daerah. Abdoel Hamid S. Attamini, menilai banyak Peraturan Daerah yang sudah bertahun-tahun akhirnya diketahui bertentangan dengan peraturan pemerintah pusat untuk itu diperlukannya jalur dokumentasi antara pusat dan daerah, sehingga mudah (dipantau) oleh pemerintah pusat. ${ }^{1}$ Dari segi pembuatannya sudah semestinya kedudukan Peraturan Daerah ini, baik Perda tingkat provinsi maupun Perda tingkat kabupaten atau kota, dapat dilihat setara dengan undang-undang dalam arti sama-sama merupakan produk hukum lembaga legislatif. Dengan demikian berdasarkan ketentuan Undang-Undang No 12 Tahun 2011, Peraturan Daerah merupakan Peraturan PerundangUndangan yang dibentuk oleh Dewan Perwakilan Rakyat Daerah dengan persetujuan bersama Kepala Daerah (Gubernur dan Bupati/walikota). Peraturan Daerah terdiri atas Peraturan Daerah Provinsi dan Peraturan Daerah Kabupaten/Kota. ${ }^{2}$

Salah satu Perda yang mempunyai fungsi strategis adalah Perda tentang Rencana Tata Ruang Wilayah (RTRW) baik provinsi maupun kabupaten/kota karena di situlah peruntukan lahan sesuai dengan fungsi kawasannya diatur. Akan tetapi penyusunan Perda RTRW ini tidaklah mudah berbeda dengan Perda-perda yang lain karena banyak kepentingan yang harus dipertimbangkan banyaknya lembaga atau institusi negara yang terlibat. Selain itu Perda RTRW ini juga tidak boleh bertentangan dan harus mengacu kepada Rencana Tata Ruang Nasional.

RTRW Provinsi merupakan pengakomodasian dari RTRW Kabupaten/Kota. Seperti halnya RTRW Kabupaten/Kota, RTRW Provinsi juga merupakan dasar dalam penyusunan RTRWNasional yang meliputi tujuan dan strategi pelaksanaan pemanfaatan ruang wilayah provinsi, rencana struktur dan pola pemanfaatan ruang, rencana umum tata ruang wilayah, dan pedoman pengendalian pemanfaatan ruang. Selain itu penyusunan RTRW Provinsi perlu mempertimbangkan arahan-arahan yang ada dalam RTRW Nasional. RTRW Nasional sendiri disusun dalam rangka menjabarkan arah pembangunan nasional yang dahulunya ada dalam Garis Garis Besar Haluan Negara (GBHN) dan Program Pembangunan Nasional (Propenas) dengan juga memperhatikan Program Pembangunan Daerah (Propeda) Kabupaten $/$ Kota. $^{3}$

Kenyataan yang terjadi akhir-akhir ini dalam implementasinya ada beberapa isu-isu strategis dalam penataan ruang nasional yaitu Pertama, terjadinya konflik kepentingan antar sektor seperti pertambangan, lingkungan hidup, kehutanan, prasarana wilayah dan sebagainya; Kedua, belum berfungsinya secara optimal penataan ruang dalam rangka menyelaraskan, mensinkronkan dan memadukan berbagai rencana dan program sektor; Ketiga, terjadinya penyimpangan pemanfaatan ruang dari ketentuan dan norma yang seharusnya ditegakkan;

\section{dan diakomodir dalam penyusunannya serta}

A.W Wijaya. Titik Berat Otonomi Pada Daerah Tingkat II. Jakarta : CV Rajawali, 1992, hlm. 51

Pasal 1 ayat 7 Undang-Undang Nomor 12 Tahun 2011 Tentang Pembentukan Peraturan Perundang-Undangan

Nina Mirantie Wirasaputri. "Proses Penyusunan Rencana Tata Ruang Dalam Kaitan Kelestarian Fungsi Lingkungan Hidup". Jurnal IImu Hukum Kanun, April 2014 : Tahun XVI,No. 62, hlm. 139. 
Keempat, belum tersedianya alokasi fungsi-fungsi yang tegas dalam Rencana Tata Ruang Wilayah Nasional (RTRWN); Kelima, belum adanya keterbukaan dan keikhlasan dalam menempatkan kepentingan sektor dan wilayah dalam kerangka penataan ruang dan Keenam, kurangnya kemampuan menahan diri dari keinginan membela kepentingan masing-masing secara berlebihan. ${ }^{4}$ Selain itu dalam penataan ruang ada 3 aspek pokok yang harus diperhatikan yaitu: (a). Aspek lingkungan hidup fisik umumnya dan sumberdaya alam khususnya yang dimanfaatkan. (b). Aspek masyarakat termasuk aspirasi sebagai pemanfaat dan (c). Aspek pengelola lingkungan fisik oleh pemerintah dan masyarakat. ${ }^{5}$

Salah satu provinsi di Indonesia yang telah menyusun Perda Tata Ruang adalah Provinsi Riau. Penyusunan Perda Rencana Tata Ruang Wilayah (RTRW) Provinsi Riau dimulai sejak adanya pemekaran daerah yaitu pemekaran daerah Provinsi Riau menjadi Provinsi Kepulauan Riau. Sebagai tindak lanjut dari pemisahan Provinsi Riau pada tahun 2004 maka untuk menyesuaikan luasan dan peruntukan lahannya, Pemerintah daerah Provinsi Riau melakukan revisi terhadap RTRW khususnya yang terkait dengan status kawasan hutan. Pemprov Riau mengusulkan perubahan kawasan hutan seluas 3,49 juta ha, sehingga kawasan hutan menjadi 3,65 juta ha dan kawasan non hutan menjadi seluas 5,39 juta ha.

Usulan Pemprov Riau tersebut direspon oleh Departemen Kehutanan pada waktu itu dengan membentuk tim terpadu pada akhir tahun 2012. Tim terpadu merekomendasikan perubahan kawasan hutan seluas 2,726 juta ha, sehingga luas kawasan hutan menjadi 4,411 juta ha dan kawasan non hutan seluas 4,62 juta ha. Setelah selama 2 tahun tidak ada progress yang berarti, maka pada tahun 2014 Departemen Kehutanan mengeluarkan SK. No. 673 Tahun 2014. Dan kemudian disusul dengan SK. No. 878 Tahun 2014 yang pada intinya menyatakan bahwa kawasan hutan di Provinsi Riau dikabulkan menjadi 5,499 juta ha atau perubahan kawasan hutan hanya seluas 1,638 juta ha dari yang diusulkan oleh tim terpadu seluass 2,726 juta ha.

Pada tanggal 20 April 2016, Kementerian Lingkungan Hidup dan Kehutanan (KLHK) menerbitkan SK. No. 314 dimana terdapat penambahan perubahan peruntukan kawasan hutan menjadi bukan kawasan hutan seluas 65,125 ha. Kemudian terbit SK. No. 393 Tahun 2016 yang merupakan revisi dari SK. No. 314 tetapi total luasannya tidak berubah. Bulan Oktober 2016 Gubernur Riau mengirimkan Ranperda RTRWP Riau 2017-2037 kepada Menteri Dalam Negeri untuk di evaluasi. Mendagri mengirimkan Ranperda RTRW Provinsi Riau tersebut kepada kementerian dan lembaga terkait untuk mendapatkan persetujuan substansial. Kementerian Lingkungan Hidup dan Kehutanan (KLHK) tidak menyetujui rancangan Peraturan Daerah RTRW Provinsi Riau. Salah satu persoalan krusial yang jadi alasan adalah perubahan peruntukan dan fungsi kawasan hutan menjadi non kawasan hutan sehingga prosesnya menjadi berlarut-larut. Kondisi ini menyita perhatian publik, sehingga Presiden RI Joko Widodo sampai turun tangan dan memanggil pihak terkait untuk menyelesaikan permasalahan ini.

4 Suwitno Y. Imran "Fungsi Tata Ruang Dalam Menjaga Kelestarian Lingkungan Hidup Kota Gorontalo". Jurnal Dinamika Hukum, September 2013 : Volume 13, Nomor 3, hlm.457-458.

5 Ahmad Jazuli. "Penegakan Hukum Penataan Ruang Dalam Rangka Mewujudkan Pembangunan Berkelanjutan". Jurnal Hukum RechtsVinding, Agustus 2017 : Volume 6, Nomor 2, hlm.279-280. 


\section{Pembahasan}

\subsection{Proses Pembentukan Peraturan Daerah Rencana Tata Ruang Provinsi Riau \\ Rancangan Peraturan Daerah (Ranperda)} yang telah disetujui bersama oleh DPRD dan Gubernur atau Bupati/Walikota, disampaikan oleh pimpinan DPRD kapada Gubernur atau Bupati/Walikota untuk ditetapkan sebagai Perda. Penyampaian Ranperda tersebut, dilakukan dalam jangka waktu paling lama tujuh hari terhitung sejak tanggal persetujuan bersama. Ranperda ditetapkan oleh Gubernur atau Bupati/walikota dalam waktu paling lama 30 hari, Perda tersebut disetujui bersama. Apabila rancangan Perda yang tidak ditetapkan oleh Gubernur atau Bupati/Walikota dalam waktu 30 hari, Perda tersebut sah menjadi Perda dan wajib diundangkan dengan memuatnya dalam lembaran daerah. Pengesahan Perda harus dirumuskan dengan kalimat pengesahan yang berbunyi "Perda ini dinyatakan sah" dengan mencantumkan tanggal sah dan kalimat pengesahan itu harus dibubuhkan pada halaman terakhir Perda, sebelum pengundangan naskah Perda ke dalam lembaran daerah.

Sebagai upaya pengawasan terhadap Perda oleh pemerintah, paling lama tujuh hari setelah ditetapkan, Perda tersebut harus disampaikan kepada pemerintah. Perda yang dinyatakan bertentangan dengan kepentingan umum dan/atau Peraturan Perundang-Undangan yang lebih tinggi dapat dibatalkan oleh pemerintah. Keputusan pembatalan perda ditetapkan dengan Peraturan Presiden paling lama 60 hari sejak diterimanya Perda yang dimaksud. Paling lama tujuh hari setelah keputusan pembatalan Perda yang dimaksud, kepala daerah harus memberhentikan pelaksanaan Perda dan selanjutnya DPRD bersama kepala daerah mencabut Perda yang dimaksud. ${ }^{6}$

Terkait dengan Proses penyusunan Perda Rencana Tata Ruang Wilayah Provinsi (RTRWP) ada beberapa tahapan yang harus dilaksanakan antara lain:

1. Pengumpulan data yang dibutuhkan dan analisis data.

2. Perumusan konsepsi RTRW Provinsi.

3. Penyusunan Ranperda RTRW Provinsi.

Prosedur penyusunan RTRW Provinsi meliputi pembentukan tim Penyusunan RTRW Provinsi, pelaksanaan penyusunan RTRW Provinsi, pelibatan peran masyarakat dalam penyusunan RTRW Provinsi, serta pembahasan Ranperda RTRW Provinsi. Keseluruhan waktu yang dibutuhkan untuk proses penyusunan dan penetapan RTRW Provinsi diupayakan seefektif mungkin, maksimal selama 24 bulan. Proses penyusunan RTRW Provinsi membutuhkan waktu antara 8 bulan sampai dengan 18 bulan. Dalam penyusunan Perda RTRW Provinsi Riau salah satu tahapan yang harus dilakukan adalah penyusunan Kajian Lingkungan Hidup Strategis (KLHS). Penyusunan KLHS RTRW Provinsi Riau 2017-2037 dilaksanakan dengan tahapan sebagai berikut:

1. Persiapan KLHS.

2. Pra pelingkupan penentuan isu strategis (daftar isu panjang).

3. Identifikasi isu paling strategis atau Critical Decision Factors (CDF) dan baseline analysis.

6 Rikardo Simarmata. Pembaharuan Hukum Daerah Menuju Pengembalian Hukum Kepada Rakyat. Jakarta : Yayasan Hukum Bantaya, 2003, hlm. 38. 
4. Pengkajian muatan Kebijakan Rencana Program (KRP) dokumen Rancangan Peraturan Daerah RTRW Provinsi Riau 2017-2037.

5. Melakukan pengkajian pengaruh KRP RTRW terhadap isu paling strategis.

6. Perumusan alternatif.

7. Penyusunan rekomendasi.

8. Penjaminan kualitas.

9. Melakukan validasi. ${ }^{7}$

Sedangkan pada tahap persiapan proses penyusunan RTRW Provinsi kegiatan yang dilakukan meliputi :

1. Persiapan awal pelaksanaan meliputi, pemahaman Kerangka Acuan Kerja (KAK), atau Terms of Reference (TOR) dan penyiapan Rencana Anggaran Biaya (RAB).

2. Kajian awal data sekunder, mencakup review RTRW Provinsi sebelumnya dan kajian kebijakan.

3. Persiapan teknis yang meliputi :

a. Penyimpulan data awal.

b. Penyiapan metodologi pendekatan pelaksanaan kerja.

c. Penyiapan perangkat survei data yang dibutuhkan, panduan wawancara, kuesioner, panduan observasi dan dokumentasi, serta mobilisasi peralatan dan personil yang dibutuhkan.

4. Pemberitaan kepada publik perihal akan dilakukan penyusunan Rencana Tata Ruang Wilayah Provinsi (RTRWP). Untuk keperluan pengenalan karakteristik tata ruang wilayah dan penyusunan tata ruang, dilakukam pengumpulan data primer dan data sekunder.

1. Pengumpulan data primer meliputi:

a. Penjaringan aspirasi masyarakat yang dapat dilaksanakan melalui penyebaran angket, temu wicara, dan wawancara perorang.

b. Pengenalan kondisi fisik dan sosialekonomi wilayah secara langsung melalui kunjungan kesemua bagian wilayah provinsi.

2. Pengumpulan data sekunder meliputi:

a. Peta Rupa Bumi Indonesia (RBI) atau peta topografi skala 1:250.000 sebagai dasar peta.

b. Citra satelit untuk memperbaharui (update) peta dasar dan membuat peta tutupan lahan, citra satelit yang digunakan harus berumur tidak lebih dari setahun yang lalu dengan menggunakan citra satelit resolusi $10 \mathrm{~m}$ $15 \mathrm{~m}$.

c. Peta batas wilayah administrasi.

d. Peta batas kawasan hutan.

e. Peta masukan untuk analisis kebencanaan.

f. Peta masukan untuk indentifikasi potensi sumber daya alam.

7 Rikardo Simarmata. Pembaharuan Hukum Daerah Menuju Pengembalian Hukum Kepada Rakyat. Jakarta : Yayasan Hukum Bantaya, 2003, hlm. 38. 
g. Data tentang kependudukan.

h. Data tentang sarana dan prasarana wilayah.

i. Data tentang petumbuhan ekonomi wilayah.

j. Data tentang kemampuan keuangan pembangunan daerah.

k. Data dan informasi tentang kelembagaan pembangunan daerah.

I. Data dan informasi tentang kebijakan penataan ruang terkait (RTRW sebelumnya dan RTRW nasional, serta RTR pulau terkait).

$\mathrm{m}$. Peraturan perundang-undangan yang terkait.

Dalam pengumpulan data perlu memperhatikan tingkat keakuratan jenis data, sumber penyediaan data, dan kewenangan sumber atau instansi penyedia data, tingkat kesalahan, variabel kepastian, serta variabel-variabel lainnya. ${ }^{8}$

Kembali kepada penyusunan Kajian Lingkungan Hidup Strategis (KLHS) yang dilakukan terhadap Rencana Tata Ruang Wilayah (RTRW) Provinsi Riau 2017-2037 merupakan wujud dari pelaksanaan peraturan perundang-undangan yang berlaku agar perencanaan pembangunan yang dilakukan telah mengintergrasikan prinsip pembangunan berkelanjutan, perencanaan pembangunan berupa pengembangan wilayah dengan mempertimbangkan aspek aspek keberlanjutan lingkungan, pertumbuhan ekonomi, dan berkeadilan secara sosial.

Berdasarkan peraturan perundangundangan, penyusunan KLHS RTRW Provinsi Riau
2017-2037 antara lain merunjuk pada UndangUndang Nomor 32 Tahun 2009 Tentang Perlindungan dan Pengelolaan Lingkungan Hidup, Peraturan Pemerintah Nomor 46 Tahun 2016 Tentang Penyelenggaraan Kajian Lingkungan Hidup Strategis, dan Peraturan Menteri Lingkungan Hidup dan Kehutanan Nomor P69/MNLHK/SETJEN/KUM.1/12/2017 Tentang Pelaksanaan Peraturan Pemerintah Nomor 46 Tahun 2016. Proses penyusunan KLHS RTRW Provinsi Riau 2017-2037 dilakukan oleh Kelompok Kerja (Pokja) KLHS yang dibentuk melalui keputusan Gubernur Provinsi Riau Nomor 817/X/2017 Tentang Pembentukan Tim Penyusun Kajian Lingkungan Hidup Strategis Rencana Tata Ruang Wilayah (KLHS RTRW) Provinsi Riau 2017-2037. Pokja KLHS terdiri dari Unsur Pemerintah Daerah, Lembaga Adat, Asosiasi Dunia Usaha, dan Lembaga Swadaya Masyarakat yang dibagi atas 3 (tiga) kelompok, yaitu kelompok kerja sosial, ekonomi, dan ingkungan. Untuk keperluan teknis, Pokja KLHS didampingi oleh tenaga ahli dari Pusat Studi Lingkungan Hidup (PSLH) Universitas Riau.

Model yang digunakan dalam penyusunan KLHS RTRW Provinsi Riau 2017-2037 menggunakan model satu peluang, di mana Kebijakan Rencana Program (KRP) Ranperda RTRW telah disusun selanjutnya dilakukan KLHS. Kerangka metodologi mengunakan pendekatan strategis untuk menciptakan konsep pembangunan berkelanjutan di masa depan, dengan penekanan pada proses, yaitu pengumpulan data, keterlibatan pemangku kepentingan, dan menciptakan jalur (Pathway) dalam mewujudkan pembangunan berkelanjutan. 
Muatan RTRW Provinsi Riau 2017-2037 yang menjadi objek KLHS secara umum terdiri dari Komponen Kebijakan (Tujuan, Kebijakan, dan Strategis), Komponen Rencana (Struktur Ruang, Pola Ruang, dan Kawasan Strategis), dan Komponen Program (Arahan Pemanfaatan Ruang). Seluruh komponen ini kemudian diidentifikasi untuk menemukan dan menentukan Kebijakan Rencana Program (KRP) yang berpotensi menimbulkan pengaruh terhadap Critical Decision Factors (CDP) Isu Prioritas Pembangunan Berkelanjutan di Provinsi. Hasil identifikasi KRP Rencana Tata Ruang Wilayah Provinsi Riau 2017-2037 menemukan 11 KRP yang berpotensi menimbulkan pengaruh terhadap Isu Paling Strategis Pembangunan Berkelanjutan di Provinsi Riau. KRP RTRW Provinsi Riau 2017-2037 yang berpotensi menimbulkan pengaruh disajikan pada Tabel berikut;

Tabel 1. KRP Berpengaruh Terhadap Isu Paling Strategis Pembangunan Berkelanjutan di Provinsi Riau

\begin{tabular}{|c|c|}
\hline No & Kebijakan, Rencana, Program RTRW Provinsi Riau \\
\hline \multicolumn{2}{|r|}{ Rencana Struktur Ruang } \\
\hline 1 & Pusat Kegiatan Wilayah yang dipromosikan (PKWp) berlokasi di Selat Panjang, Kuala \\
\hline 1 & Enok dan Tanjung Buton. \\
\hline 2 & Jaringan Kereta Api \\
\hline 3 & Sistem Bendungan Rokan Kiri di Kabupaten Rokan Hulu \\
\hline
\end{tabular}

\section{Rencana Pola Ruang}

1 Kawasan Peruntukan Hutan Produksi

2 Kawasan Peruntukan Pertanian

3 Outline

\section{Rencana Kawasan Strategis}

$1 \quad$ Kawasan strategis provinsi

\section{Arahan Pemanfaatan Ruang/Indikasi Program}

1 Pembangunan Jalan Bebas Hambatan

2 Pembangunan Jalan dan Jembatan Lingkar Tenggara-Pekanbaru

3 Pembangunan Jalan dan Jembatan Lingkar Barat-Duri

4 Program Pengembangan Pembangunan Kawasan Pariwisata 
Sedangkan hasil analisis dari pengaruh Strategis RTRW Provinsi Riau disajikan pada Tabel Kebijakan Rencana Program (KRP) terhadap Isu berikut:

Tabel 2. Hasil Analisis Pengaruh KRP Terhadap Isu Strategis RTRW Provinsi Riau 2017-2037

\begin{tabular}{|c|c|c|c|c|c|c|c|c|}
\hline \multirow{2}{*}{ No } & \multirow{2}{*}{$\begin{array}{l}\text { Kebijakan, Rencana, } \\
\text { RTRWP Riau }\end{array}$} & \multicolumn{7}{|c|}{ Analisi Pengaruh } \\
\hline & & 1 & 2 & 3 & 4 & 5 & 6 & 7 \\
\hline \multicolumn{9}{|c|}{ Rencana Struktur Ruang } \\
\hline 1 & $\begin{array}{l}\text { Pusat Kegiatan Wilayah yang } \\
\text { dipromosikan (PKWp) berlokasi di } \\
\text { selat panjang, kuala enok, dan } \\
\text { tanjung buton }\end{array}$ & $\cdot$ & - & - & 0 & 0 & - & - \\
\hline 2 & Jaringan Kereta Api & 0 & - & 0 & + & 0 & - & - \\
\hline 3 & $\begin{array}{l}\text { Sistem Bendungan Rokan Kiri di } \\
\text { Kabupaten Rokan Hulu }\end{array}$ & - & - & + & + & + & - & - \\
\hline \multicolumn{9}{|c|}{ Rencana Pola Ruang } \\
\hline 1 & Kawasan peruntukan hutan produksi & + & + & + & + & + & + & + \\
\hline 2 & Kawasan peruntukan pertanian & + & - & + & - & 0 & - & - \\
\hline 3 & Outline & - & - & - & - & - & - & + \\
\hline \multicolumn{9}{|c|}{ Rancana Kawasan Strategis } \\
\hline 1 & Kawasan Strategis Provinsi & - & - & - & - & - & - & - \\
\hline
\end{tabular}

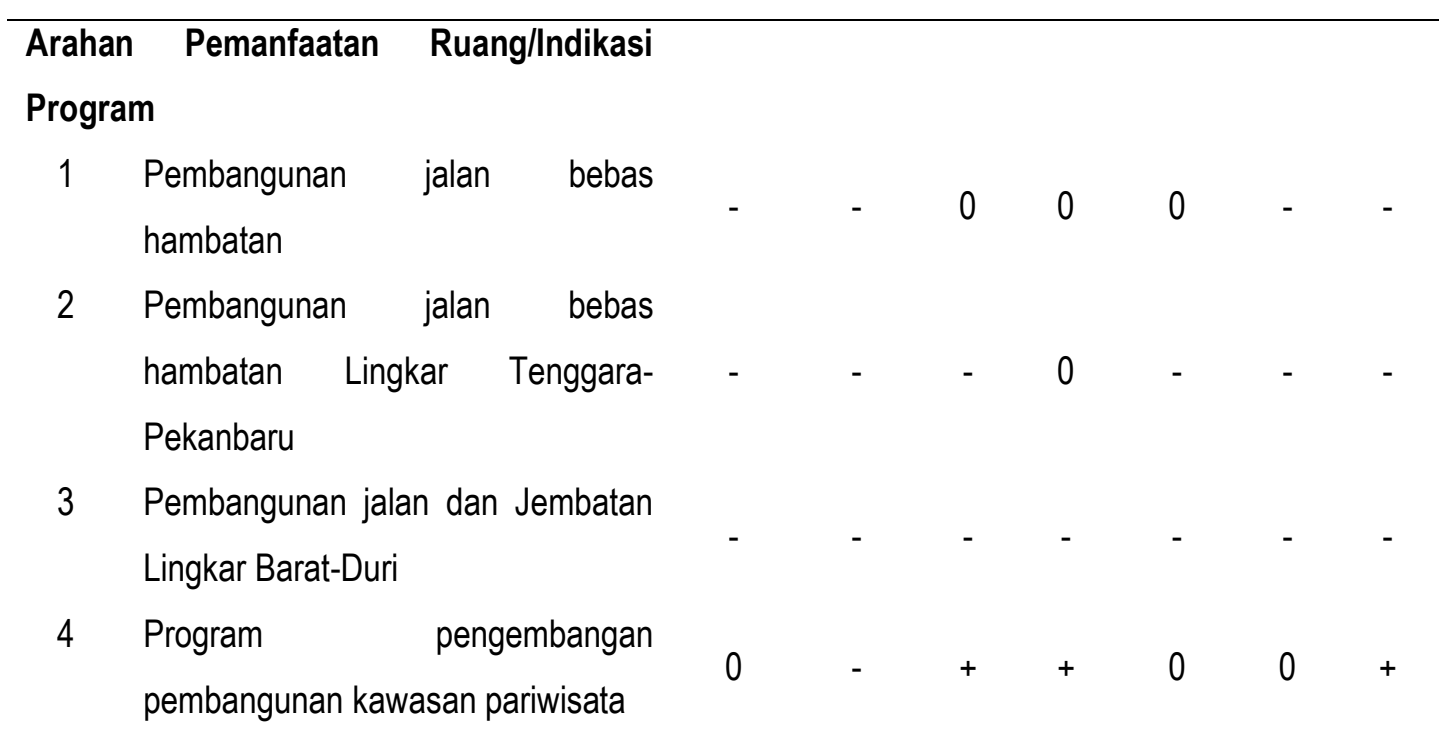

Keterangan : (-) Pengaruh Negatif, (+) Pengaruh Positif, (0) Tidak Berpengaruh.

Sumber : Sekretariat DPRD Provinsi Riau 
Mekanisme Panitia Khusus (Pansus) dalam melakukan pembahasan terhadap Ranperda RTRW Provinsi Riau 2017-2037, Pansus mengacu pada mekanisme pembahasan berdasarkan tahapantahapan yang lazim dilakukan di lingkungan DPRD Provinsi Riau dan berpedoman pada Permendagri Nomor 80 Tahun 2015 Tentang Pembentukan Produk Hukum Daerah. Secara ringkas dapat dirinci antara lain sebagai berikut:

1. Gubernur Riau mengajukan usulan tentang Ranperda RTRW Provinsi Riau ke DPRD Provinsi Riau.

2. Kemudian Ranperda ditelaah oleh BP2D Provinsi Riau yang diberi tugas oleh pimpinan DPRD.

3. Hasil telaah BP2D berbentuk rekomendasi yang akan disampaikan dalam sidang paripurna melalui Badan Permusyawaratan (Bamus) DPRD Provinsi Riau.

4. Setelah direkomendasikan dalam rapat paripurna kemudian dibentuk alat kelengkapan DPRD yang disebut Pansus (Panitia Khusus).

5. Lalu Pansus bekerja sesuai tata tertib DPRD Provinsi Riau mengadakan rapat pembahasan dengan OPD terkait seperti BAPPEDA Provinsi Riau, BPN Provinsi Riau, Bupati Seprovinsi Riau, LAM, Biro Hukum Provinsi Riau, Kadin, dan Dinas Kehutanan.

6. Setelah merangkum usulan-usulan berdasarkan rapat pembahasan Pansus dengan OPD terkait kemudian hasil kesepakatan Ranperda RTRW Provinsi
Riau disampaikan dalam rapat paripurna DPRD Provinsi Riau, 2/3 Kuorum dari DPRD untuk mengambil keputusan persetujuan DPRD Provinsi Riau dan Gubernur Provinsi Riau.

7. Hasil keputusan DPRD Provinsi Riau terhadap persetujuan rapat paripurna disampaikan kepada Gubernur Riau selama 3 hari setelah sidang paripurna.

8. Gubernur Riau menyampaikan Draft Ranperda RTRW Provinsi Riau kepada Kemendagri untuk dievaluasi.

9. Kemudian Kemendagri mengundang Kementerian terkait Kementerian LHK, Dirjen Planologi, Kemenko Perekonomian, BPN Provinsi Riau, Kemen PPN/BAPPENAS, Kementerian Agraria dan Tata Ruang, Ombudsman RI dan Badan Informasi Geospasial.

10. Mendagri menerbitkan Kepmendagri No 188.34-8552/2017 Tentang Evaluasi Ranperda Provinsi Riau Tentang RTRW Provinsi Riau Tahun 2017-2037.

11. Hasil keputusan evaluasi RTRW Provinsi Riau dibahas kembali oleh Gubernur Riau melalui perangkat daerahnya bersama DPRD Provinsi Riau untuk diklarifikasi kembali.

12. Gubernur Riau mengirim surat No 050/BAPPEDA/52.02 perihal permohonan validasi Dokumen KLHS RTRW Provinsi Riau ke Kementerian LHK c.q Dirjen Planologi Kehutanan dan Tata Lingkungan. 
13. Kepala Badan Informasi Geospasial dan Kementerian Agraria dan Tata Ruang menyetujui penetapan RTRW Provinsi Riau sesuai hasil rapat dengan Pemerintah Daerah.

14. BAPPENAS menyetujui dan menerbitkan Surat Rekomendasi Penyusunan Peta Rencana Tata Ruang Wilayah (RTRW) Provinsi Riau No. RTRW 12/BIG/PTRA/10/2017 tentang Proses pengesahan Perda RTRW Provinsi Riau.

15. Dirjen Planologi Kehutanan dan Tata Lingkungan Kementerian LHK menanggapi dengan mengirim surat berisi masih ada ketidaksesuaian antara KLHS RTRW Provinsi Riau 2017-2037 dengan penjaminan kualitasnya.

16. Gubernur Riau mengirim surat No.050/BAPPEDA/44.06 perihal tindaklanjut Validasi Dokumen KLHS RTRW Provinsi Riau dan menyampaikan hasil rapat koordinasi perkembangan penyusunan KLHS RTRW Provinsi Riau 2017-2037.

17. Kementerian LHK mengirim surat No.S.418/MENLHKPKT/PDLKWS/PLA./3/4/2018 ke Gubernur Riau perihal Validasi KLHS RTRW Provinsi Riau 2017-2037.

18. Sekda mengirimkan surat No.180/HK/35.08 Perihal Permintaan Nomor Register Ranperda ke Mendagri, c/q. Direktur Produk Hukum Daerah Ditjen Otonomi Daerah.
19. Digelar Rakor verifikasi hasil evaluasi terhadap 26 catatan sesuai Kepmendagri No.188.34-9552/2017 dan telah ditindaklanjuti oleh Pemerintah Provinsi Riau.

20. Direktur Produk Hukum Daerah, Ditjen Otda Kemendagri mengirim surat No.70/Reg/PHD/IV/2018 perihal pemberian Nomor Register Ranperda ke Sekda Provinsi Riau dengan Nomor Register (10,105/2018).

21. Gubernur Riau menetapkan Perda No 10 Tahun 2018 Tentang Rencana Tata Ruang Wilayah (RTRW) Provinsi Riau.

Permasalahan mendasar sehingga pembentukan Perda RTRW Provinsi Riau berlarutlarut adalah adanya tarik menarik kepentingan antara pemerintah pusat dalam hal ini Kementerian Lingkungan Hidup dan Kehutanan dengan pemerintah daerah Provinsi Riau terkait dengan peruntukan lahan dari Kawasan Hutan ke Kawasan Non Hutan. Usulan pemerintah provinsi Riau dari hasil rekomendasi Tim Terpadu ternyata tidak diakomodir oleh Kementerian Lingkungan Hidup dan Kehutanan yaitu perubahan peruntukan lahan dari Kawasan Hutan menjadi Kawasan Non Kehutanan seluas 2.726.901 ha. Berdasarkan surat Menteri Kehutanan No. SK. 673/Menhut-II/2014 tentang Perubahan Kawasan Hutan menjadi Bukan Kawasan Hutan, Kementerian Lingkungan Hidup dan Kehutanan (LHK) hanya menyetujui seluas 1.638.249 ha. Padahal faktanya di lapangan areal atau lahan yang dipertahankan oleh Kementerian LHK itu sudah berubah sebagian besarnya menjadi 
areal perkebunan kelapa sawit dan peruntukan lainnya.

Salah satu upaya pemerintah provinsi Riau untuk mengatasi persoalan tersebut di masa yang akan datang adalah dengan mengusulkan adanya Holding Zone atau Outlet seluas 405.874 ha seperti yang tertera pada Tabel 3, yang akan digunakan untuk pemukiman, transmigrasi, infrastruktur, fasos, fasum, perkebunan rakyat, tambak dan lain lain. Tetapi terhadap areal seluas kurang lebih 700.000 ha harus tetap dikembalikan kepada peruntukan semula yaitu menjadi kawasan hutan. Hal ini tentunya akan menjadi permasalahan tersendiri di kemudian hari karena fakta di lapangan areal tersebut sudah berubah menjadi kebun kelapa sawit walaupun tentunya itu kebun illegal karena berada di atas lahan kawasan hutan. Kalau pemerintah konsisten dengan kebijakan tersebut maka mau tidak mau kebun kelapa sawit tersebut harus ditebang dan arealnya dibiarkan kembali menjadi hutan atau dihutankan kembali.

Oleh karena itu Kementerian Lingkungan Hidup dan Kehutanan sebagai institusi yang mempunyai otoritas di bidang kehutanan harus membuat regulasi yang mengatur tatacara dan tenggat waktu sampai kapan lahan kelapa sawit tersebut harus ditebang dan dihutankan kembali karena kalau tidak, hal ini akan menjadi preseden buruk dan akan menimbulkan ketidakpastian hukum karena Perda tataruangnya tidak efektif.

Pelaksanaan RTRW Provinsi sangat dipengaruhi oleh komitmen dari pemerintah daerah itu sendiri, karena seringkali terjadi tarik menarik kepentingan. Pada satu sisi pemerintah ingin menciptakan pengaturan ruang yang baik, akan tetapi pada sisi lain ingin mendapatkan manfaat/keuntungan dari mekanisme pasar. Berdasarkan hal itu, pemerintah seringkal menempuh jalan kompromi yaitu mengorbankan rencana tataruang yang sudah dibuat dengan melakukan revisi sebelum masa berlakunya berakhir. ${ }^{9}$

Pembentukan Perda adalah pekerjaan yang cukup rumit terutama terhadap Perda yang terkait dengan areal atau lahan. Dalam pembentukan Perda dituntut kesempurnaan dalam hal sistematika, tatanan, bahasa, istilah, dan juga banyaknya berbagai jenis materi yang akan diatur sesuai dengan kebutuhan. Oleh karena itu dalam persiapan pembuatannya membutuhkan pengetahuan mendalam tehadap materi yang akan diatur dan memerlukan analisis serta pengamatan yang komprehensif. Selain itu juga harus mampu untuk menemukan inti dari fakta-fakta yang ada dan berkembang dilapangan untuk dituangkan kedalam bentuk peraturan yang ringkas dan dengan bahasa yang jelas.

Dari data dan fakta yang ada, salah satu faktor terlambatnya pembentukan Perda RTRW Provinsi Riau pada dasarnya dikarenakan khusus untuk Perda Tata Ruang, Kemendagri terlebih dahulu harus meminta rekomendasi dari instansi dan kementerian terkait antara lain dari Kepala BAPPENAS, Badan Informasi Geospasial dan Kementerian Agraria dan Tata Ruang serta Kementerian LHK. Kementerian LHK tidak bersedia memberi rekomendasi karena Pemerintah Daerah tidak mengikuti dan tidak berpedoman pada peta yang digunakan oleh Kementerian LHK dimana Kementerian LHK mengacu pada Peta Tata Guna

9 Setio Widodo. "Rencana Tata Ruang Wilayah Dalam Perspektif Perencanaan Pembangunan Wilayah". Jurnal Ilmiah Administrasi Publik (JIAP), Tahun 2017 : Volume 3, Nomor 3, hlm.169 
Hutan Kesepakatan (TGHK). Tetapi Kementerian LHK merekomendasi Perda RTRW permasalahannya adalah fakta di lapangan setelah disurvei areal tersebut sudah berubah menjadi kebun kelapa sawit dan lain-lain. Untuk itu kebijakan dari pemerintah Provinsi Riau adalah mengubah areal tersebut menjadi Kawasan Non Hutan atau kawasan perkebunan, tetapi Kementerian LHK tetap bertahan dengan sikapnya agar Pemerintah Daerah mengubah kawasan perkebunan menjadi kawasan hutan dengan cara melakukan pengosongan kebun kelapa sawit atau penghutanan kembali. Pada akhirnya Pemerintah Daerah menyetujui kebijakan yang diajukan oleh Kementerian LHK sehingga Provinsi Riau. Pada tanggal 25 April 2018 Perda RTRWP Provinsi Riau disetujui oleh Kemendagri melalui Direktur Produk Hukum Daerah, Ditjen Otonomi Daerah dan memberikan Nomor Registrasi Peraturan Daerah RTRW Provinsi Riau $(10,105 / 2018)$ dan setelah itu Gubernur Riau menetapkan menjadi Peraturan Daerah Nomor 10 Tahun 2018 Tentang Rencana Tata Ruang Wilayah Provinsi Riau.

Rincian alokasi kawasan Outline atau Holding Zone dalam Rencana Tata Ruang Wilayah Provinsi Riau adalah seperti Tabel berikut:

Tabel 3. Penetapan Kawasan Holding Zone atau Outline Rencana Tata Ruang Wilayah Provinsi Riau 20182038

\begin{tabular}{|c|c|c|c|c|c|c|c|c|}
\hline \multirow{3}{*}{ No } & \multicolumn{8}{|c|}{ Luas pada SK. } \\
\hline & \multirow{2}{*}{$\begin{array}{c}\text { Peruntukan } \\
\text { Kawasan }\end{array}$} & \multicolumn{6}{|c|}{ 903/MenLHK/SEKJEN/PLA.2/12/206 } & \multirow{2}{*}{$\begin{array}{l}\text { Luas } \\
\text { (Ha) }\end{array}$} \\
\hline & & $\mathrm{HL}$ & HP & HPK & HPT & $\begin{array}{c}\mathrm{KSA} / \mathrm{KP} \\
\mathrm{A}\end{array}$ & APL & \\
\hline \multirow{3}{*}{$\begin{array}{l}1 \\
2\end{array}$} & Pemukiman & 3.415 & 7.309 & 6.315 & 3.563 & 1.852 & - & 19.317 \\
\hline & Insfrastruktur,fas & & & & & & & \\
\hline & $\begin{array}{l}\text { ilitas sosial, dan } \\
\text { fasilitas umum }\end{array}$ & 235 & 3.232 & 1.309 & 2.148 & 72 & - & 7.078 \\
\hline 3 & Industri & - & - & 306 & 93 & - & - & 399 \\
\hline 4 & $\begin{array}{l}\text { Perkebunan } \\
\text { Rakyat }\end{array}$ & 34.319 & 23.269 & 259.092 & 34.319 & 13 & - & 321.717 \\
\hline 5 & Hutan Lindung & - & - & - & - & - & 1.798 & 1.798 \\
\hline 6 & $\begin{array}{l}\text { Kawasan } \\
\text { Perikanan }\end{array}$ & - & - & - & 183 & - & - & 183 \\
\hline 7 & $\begin{array}{l}\text { Kawasan } \\
\text { Pertanian }\end{array}$ & - & 59 & 1.751 & 44.488 & 9.056 & - & 55.355 \\
\hline & Total & 5.596 & 35.562 & 311.592 & 49.363 & 10.908 & 1.798 & 405.847 \\
\hline
\end{tabular}

Sumber : Sekretariat DPRD Provinsi Riau 
2.2. Kedudukan Perda Tentang Tata Ruang Wilayah Provinsi Berdasarkan UndangUndang Nomor 12 Tahun 2011 Tentang Pembentukan Peraturan PerundangUndangan

Kalau dilihat dalam Undang-Undang Nomor 12 Tahun 2011 Tentang Pembentukan Peraturan Perundang-Undangan tidak dijelaskan adanya perbedaan kedudukan antara Perda RTRW Provinsi dengan Perda lain, yang mana dalam undangundang tersebut Perda RTRW Provinsi dengan Perda lainnya memiliki kedudukan yang sama pada proses pembentukannya. Perda RTRW Provinsi dan perda lainnya termasuk dalam prolegda (Program Legislasi Daerah). Tetapi pada kenyataannya dalam proses penyusunan Perda RTRW Provinsi Riau banyak Instansi dan Kementerian terkait seperti Kementerian Lingkungan Hidup dan Kehutanan, Kementerian Perencanaan Pembangunan Nasional/BAPPENAS, Kementerian Agraria dan Tata Ruang, Badan Informasi Geospasial dan Kementerian Dalam Negeri yang ikut terlibat dalam membahas dan menyusun Perda RTRW Provinsi. Selain itu proses pembentukan Perda RTRW lebih rumit dan membutuhkan waktu yang cukup lama. Sedangkan Perda lain tidak banyak instansi atau kementerian yang terlibat yaitu hanya Kemendagri.

Perda dibagi menjadi dua bentuk, Perda Provinsi dan Perda Kabupaten/Kota. Dalam Pasal 7 ayat (1) UU No.12 Tahun 2011, Peraturan Daerah merupakan jenis peraturan perundang-undangan yang kedudukannya di bawah Peraturan Presiden. Perda merupakan jenis peraturan perundang- undangan yang pembentukannya melibatkan lembaga perwakilan. Itu sebabnya jenis peraturan perundang-undangan tersebut mempunyai keistimewaan dalam hal materi muatannya. Perda mempunyai keistimewaan karena dapat memuat ketentuan pidana dalam materi muatannya, Perda juga merupakan jenis peraturan perundangundangan yang jenis dan kedudukannya diatur dalam UUD $1945 .{ }^{10}$

Penerapan hirarki peraturan perundangundangan tidak lepas dari pengaruh politik yang kemudian membentuk sistem ketatanegaraan $d i$ Indonesia. Seperti disampaikan oleh Satjipto Rahardjo, bahwa hukum bukanlah suatu lembaga yang otonom, melainkan berada pada kedudukan yang kait-mengait dengan sektor-sektor kehidupan lain dalam masyarakat. Hierarki peraturan perundang-undangan tidak lepas dari sistem ketatanegaraan di Indonesia. Bahkan hal tersebut sudah dimulai sejak masa kolonial Belanda di Indonesia yakni sejak tahun 1800 sampai dengan 1942. Demikian juga pada masa pendudukan Jepang dari tahun 1942 sampai 1945. ${ }^{11}$

Keberadaan peraturan daerah dalam sistem perundang-undangan di Indonesia sudah ada sejak zaman pemerintahan Hindia Belanda. Pada masa ini sistem perundang-undangan yang berlaku tidak dapat dipisahkan dari sistem perundangundangan di Kerajaan Belanda. ${ }^{12}$ Setelah Indonesia merdeka, dengan berlakunya UUD 1945 sebagai UUD Republik Indonesia maka sistem hukum dan pemerintahan Indonesia berdasarkan UUD $1945 .^{13}$ Hakikat Perda sebagai sarana penampung kondisi khusus di daerah merupakan sebuah karateristik

10 Ahmad Yani. Pembentukan Undang-Undang dan Perda. Jakarta : Rajawali Pers, 2011, hlm. 13.

11 Satjipto Rahardjo. IImu Hukum. Bandung : Citra Aditya Bakhti, 2006, hlm. 358.

12 Imam Soebechi. Hak Uji Materiil. Jakarta : Sinar Grafika, 2016, hlm. 106.

13 Ibid, hlm. 107 
perda yang tidak dimiliki oleh peraturan perundangundangan lainnya, yang hanya memposisikan peraturan perundang-undangan dimaksud sebagai alat hukum tertulis untuk kepentingan nasional semata. Hakikat Perda sebagai sarana penampung kondisi khusus di daerah merupakan fungsi Perda yang tidak hanya sebagai penjabaran lebih lanjut dari peraturan perundang-undangan nasional, akan tetapi juga menjadi sarana hukum dalam memperhatikan ciri khas daerah. ${ }^{14}$

Menurut Rikardo Simarmata, Perda memiliki porsi paling penting diantara produk hukum daerah yang lain. Perda adalah sumber utama dari produk hukum daerah, bukan hanya karena ia merupakan penerjemah pertama dari peraturan perundangan diatasnya tapi juga karena merupakan ekspresi dari kebutuhan daerah. ${ }^{15}$ Perda dibentuk dalam rangka penyelenggaraan otonomi dan tugas pembantuan serta merupakan penjabaran lebih lanjut dari peraturan perundang-undangan yang lebih tinggi dengan memperhatikan ciri khas masingmasing daerah. ${ }^{16}$

Pada tahun 2011 dikeluarkan UndangUndang Nomor 12 Tahun 2011 Tentang Pembentukan Peraturan Perundang-undangan. Dasar pertimbangan peraturan perundangundangan adalah bahwa dalam rangka pembangunan hukum nasional, pembentukan peraturan perundang-undangan hanya dapat terwujud apabila didukung oleh cara dan metode yang pasti, baku, dan standar yang mengikat semua lembaga yang berwenang membuat peraturan perundang-undangan. Sistem peraturan perundangundangan Indonesia menempatkan pancasila sebagai sumber dari segala sumber hukum negara. Dalam penjelasan Pasal 2 disebutkan bahwa penempatan Pancasila sebagai sumber dari segala sumber hukum negara adalah sesuai dengan pembukaan UUD Negara Republik Indonesia Tahun 1945 alinea keempat. Menempatkan Pancasila sebagai dasar dan ideologi negara serta sekaligus filosofis negara sehingga setiap materi muatan peraturan perundang-undangan tidak boleh bertentangan dengan nilai-nilai yang terkandung dalam Pancasila.

Undang-Undang Dasar Negara Republik Indonesia Tahun 1945 merupakan hukum dasar dalam peraturan perundang-undangan. Penjelasan Pasal 2 ayat (1) menyebutkan bahwa yang dimaksud dengan "hukum dasar" adalah norma dasar bagi pembentukan peraturan perundang-undangan dibawah UUD Negara Republik Indonesia Tahun 1945. Sesuai ketentuan Pasal 7 ayat (1) UU Nomor 12 Tahun 2011, jenis dan hirarki peraturan perundang-undangan terdiri atas:

1. UUD Negara Republik Indonesia Tahun 1945

2. Ketetapan Majelis Permusyawaratan Rakyat

3. Undang-Undang/ Peraturan Pemerintah Pengganti Undang-Undang

4. Peraturan Pemerintah

5. Peraturan Presiden

6. Peraturan Daerah Provinsi

7. Peraturan Daerah Kabupaten. ${ }^{17}$

Dari semua jenis dan hirarki peraturan perundang-undangan yang ada, menurut ketentuan Pasal 15 UU No 12 Tahun 2011, hanya dua jenis

\footnotetext{
14 Kuntana Magnar. Pokok-Pokok Pemerintahan Daerah Otonom dan Wilayah Administratif. Bandung : Armico, 1984, hlm. 22.

15 Rikardo Simarmata. Pembaharuan Hukum Daerah...Op., Cit., hlm. 23.

16 Ni'matul Huda, dkk. Teori dan Pengujian Peraturan Perundang-Undangan. Yogyakarta : Nusa Media, 2011 , hlm. 110.

17 Ibid, hlm. 113.
} 
peraturan yang materi muatannya memuat ketentuan pidana yaitu Undang-Undang dan Peraturan Daerah Provinsi serta Peraturan Daerah Kabupaten/Kota. ${ }^{18}$ Dalam penjelasan Pasal 7 ayat (5) ditegaskan bahwa "dalam ketentuan ini dimaksud dengan hierarki adalah penjenjangan setiap Peraturan Perundang-undangan yang didasarkan pada asas bahwa Peraturan Perundang-undangan yang lebih rendah tidak boleh bertentangan dengan Peraturan Perundang-undangan yang lebih tinggi." 19

Peraturan perundang-undangan yang lebih rendah tidak boleh bertentangan dengan peraturan perundang-undangan yang lebih tinggi. Apabila peraturan perundang-undangan yang lebih rendah tingkatannya bertentangan dengan peraturan perundang-undangan yang lebih tinggi, peraturan perundang-undangan yang lebih rendah dapat dituntut untuk dibatalkan demi hukum (Van Rechtswege Nietig). Tata urutan atau hirarki peraturan perundang-undangan dalam suatu tata hukum oleh Hans Kelsen disebut (Grundnorm). ${ }^{20}$

Pada saat ini Perda mempunyai kedudukan yang kuat dan sangat strategis karena diberikan landasan konstitusional yang jelas sebagaimana diatur dalam Pasal 18 ayat 6 UUD 1945. ${ }^{21}$

Perlu diingat, Perda dibuat oleh satuan pemerintahan yang mandiri (otonom) dengan lingkungan wewenang mandiri. Karena itu pengujiannya terhadap peraturan perundangundangan tingkat lebih tinggi tidak boleh sematamata berdasarkan tingkatannya, melainkan pada lingkungan wewenangnya. Suatu Perda yang bertentangan dengan peraturan perundangundangan lebih tinggi tingkatannya (kecuali UUD
1945) belum tentu salah, kalau ternyata peraturan perundang-undangan yang lebih tinggi justru yang melanggar hak dan wewenang daerah yang dijamin UUD 1945 atau undang-undang Pemerintah Daerah.

Hakikat Perda dalam sistem perundangundangan nasional merupakan justifikasi terhadap eksistensi perda yang tidak terlepas dari hierarki peraturan perundang-undangan, dimana menempatkan posisi perda di bawah UUD 1945, Undang-Undang/Peraturan Pemerintah Pengganti Undang-Undang (PERPU), Peraturan Pemerintah dan Peraturan Presiden. Sehingga dapat dikatakan bahwa hakikat Perda Provinsi dan Perda Kabupaten/Kota sebagai bagian dari sistem perundang-undangan nasional berarti menempatkan perda sebagai penjabaran lebih lanjut dari peraturan perundang-undangan yang lebih tinggi.

Oleh karena pentingnya kedudukan Perda khususnya Perda tentang rencana tataruang maka sudah selayaknya peraturan pelaksanaan dalam pembentukan perda rencana tata ruang provinsi diatur dalam bentuk Peraturan Presiden (Perpres) bukan dengan peraturan menteri dalam negeri. Hal ini karena dalam penyusunan Perda rencana tataruang provinsi melibatkan beberapa institusi negara dan kementerian seperti Kementerian Dalam Negeri, Kementerian Lingkungan Hidup dan Kehutanan, Kementerian Agraria dan Tata Ruang, Bappenas dan Badan Informasi Geospasial.

\section{Penutup}

\section{1. Kesimpulan}

Setelah melalui proses yang sangat panjang maka pembentukan peraturan daerah

18 Ibid, hlm. 114.

19 Ibid, hlm. 115.

20 Ni'matul Huda. "Kedudukan Peraturan Daerah Dalam Hierarki Peraturan Perundang-Undangan." Jurnal Hukum IusQuia lusTum, Januari 2006 : No. 1, Vol. 13, hlm. 30.

21 Arifin. "Peraturan Daerah Dalam Sistem Hukum dan Implementasi Terhadap Otonomi Daerah". Jurnal IImu Hukum Legal Opinion, Tahun 2015 : Edisi 1, Volume. 3, hlm. 5. 
(Perda) Rencana Tata Ruang Wilayah (RTRW) Provinsi Riau akhirnya disetujui oleh Kemendagri dan ditetapkan oleh Gubernur Riau menjadi Perda No.10 Tahun 2018 Tentang Rencana Tata Ruang Wilayah Provinsi Riau dengan perincian sebagai berikut : (1). Kawasan Budidaya seluas $=8.067 .344$ ha dan (2). Kawasan Lindung seluas $=945.532 \mathrm{ha}$, dengan total luas keseluruhan sebesar 9.012.876 ha. Walaupun Perda tentang RTRW Provinsi Riau telah ditetapkan akan tetapi masih ada permasalahan yang harus diselesaikan yaitu menyangkut pengosongan areal yang telah menjadi perkebunan kelapa sawit di kawasan hutan untuk nantinya dihutankan kembali. Hal ini bukanlah pekerjaan mudah karena harus menebang pohon kelapa sawit dengan luasan ratusan ribu hektar.

Berdasarkan Undang-Undang Nomor 12 Tahun 2011 Tentang Pembentukan Peraturan Perundang-Undangan tidak ada perbedaan antara Perda RTRW dengan Perda-Perda yang lain baik dalam hal kedudukan maupun tatacara pembentukannya. Padahal dalam prakteknya, proses pembentukan Perda Tata Ruang Wilayah Provinsi melibatkan banyak instansi dan kementerian antara lain Kementerian Dalam Negeri, Kementerian Lingkungan Hidup dan Kehutanan, Kementerian Perencanaan Pembangunan Nasional/BAPPENAS, Kementerian Agraria dan Tata Ruang dan Badan Informasi Geospasial.

\section{2. Saran}

Perlu dibuat regulasi oleh Kementerian Lingkungan Hidup dan Kehutanan terkait dengan pengaturan tentang tatacara dan batas waktu pengosongan areal kawasan hutan yang telah berubah menjadi perkebunan kelapa sawit. Selain itu aturan pelaksanaan tentang tata cara pembentukan Perda Rencana Tata Ruang Wilayah Provinsi sebaiknya dalam bentuk Peraturan Presiden (Perpres) tidak cukup hanya dengan Peraturan Menteri Dalam Negeri. Hal ini dikarenakan pembentukan Perda Tata Ruang Wilayah Provinsi melibatkan beberapa kementerian dan lembaga negara.

\section{DAFTAR PUSTAKA}

\section{A. Buku}

Huda, Ni'matul, et. al. Teori dan Pengujian Peraturan Perundang-Undangan. Yogyakarta : Nusa Media, 2011.

Magnar, Kuntana. Pokok-Pokok Pemerintahan Daerah Otonom dan Wilayah Administratif. Bandung : Armico, 1984

Rahardjo, Satjipto. IImu Hukum. Bandung : Citra Aditya Bakti, 2006

Simarmata, Rikardo. Pembaharuan Hukum Daerah Menuju Pengembalian Hukum Kepada Rakyat. Jakarta :Yayasan Hukum Bantaya, 2003.
Soebechi, Imam. Hak Uji Materiil. Jakarta : Sinar Grafika, 2016

Wijaya, A.W. Titik Berat Otonomi Pada Daerah Tingkat II. Jakarta : CV Rajawali, 1992.

Yani, Ahmad. Pembentukan Peraturan Perundangundangan Yang Reponsif (Catatan atas Undang-Undang Nomor 12 Tahun 2011 Tentang Pembentukan Peraturan Perundangundangan). Jakarta : Konstitusi Pers, 2013.

\section{B. Jurnal/Artikel/Skripsi}

Arifin. "Peraturan Daerah Dalam Sistem Hukum dan Implementasi Terhadap Otonomi Daerah". 
Jurnal IImu Hukum Legal Opinion,Tahun 2015 : Edisi1, Volume 3.

Huda, Ni'matul. "Kedudukan Peraturan Daerah Dalam Hierarki Peraturan PerundangUndangan". Jurnal Hukum IusQuia IusTum, Januari 2006 : No. 1 Vol. 13.

Imran, Suwitno Y. "Fungsi Tata Ruang Dalam Menjaga Kelestarian Lingkungan Hidup Kota Gorontalo". Jurnal Dinamika Hukum, September 2013 : Volume 13, Nomor 3.

Jazuli, Ahmad."Penegakan Hukum Penataan Ruang Dalam Rangka Mewujudkan Pembangunan Berkelanjutan". Jurnal Hukum RechtsVinding, Agustus 2017 : Volume 6, Nomor 2

Widodo, Setio. "Rencana Tata Ruang Wilayah Dalam Perspektif Perencanaan Pembangunan Wilayah". Jurnal IImiah Administrasi Publik (JIAP), Tahun 2017 : Volume 3, Nomor 3.

Wijaya, Rudi. "Pembentukan Perda Tata Ruang Berdasarkan Undang-Undang Nomor 12
Tahun 2011 Tentang Pembentukan Peraturan Perundang-Undangan (Studi Terhadap Perda RTRW Provinsi Riau)". Skripsi Fakultas Hukum UIR, 2019.

Wirasaputri, Nina Mirantie."Proses Penyusunan Rencana Tata Ruang Dalam Kaitan Kelestarian Fungsi Lingkungan Hidup". Jurnal Ilmu Hukum Kanun, April 2014:No 62 Tahun XVI.

\section{Peraturan Perundang-undangan}

Undang-Undang Nomor 26 Tahun 2007 Tentang Penataan Ruang.

Undang-Undang Nomor 12 Tahun 2011 Tentang Pembentukan Peraturan PerundangUndangan.

Undang-Undang Nomor 23 Tahun 2014 Tentang Pemerintahan Daerah.

Permendagri Nomor 80 Tahun 2015 Tentang Pembentukan Produk Hukum Daerah 